\title{
SUSTAINABILITY OF A SMALL FIRM - THE ENTREPRENEURIAL PERSPECTIVE
}

doi: 10.2478/cqpi-2019-0019

Date of submission of the article to the Editor: 02/04/2019

Date of acceptance of the article by the Editor: 15/05/2019

Piotr Tomski ${ }^{1}$ - orcid id: 0000-0002-8561-8445

Faiza Manzoor ${ }^{2}$ - orcid id: 0000-0002-4106-0910

${ }^{1}$ Czestochowa University of Technology, Poland

${ }^{2}$ Department of Agricultural Economics and Management, Zhejiang University, Hangzou, China Abstract: The objective of the paper is to analyze the perception of sustainable performance of entrepreneurs being owners-managers of small businesses. The research tool was the questionnaire.

Keywords: sustainable development, sustainable performance, small business

\section{INTRODUCTION}

Sustainability refers to a society in which an appropriate balance is created between economic, social and ecological objectives. For enterprises, this involves sustaining and expanding economic growth, shareholder value, prestige, corporate reputation, customer relationships and the quality of products and services. It also means adopting and pursuing ethical business practices, creating sustainable jobs, building value for all the company's stakeholders and attending to the needs of the underserved (Szekely and Knirsch, 2005). In this approach enhanced performance of economic entities should be assessed not only in terms of the value of services, manufactured products and profits but also in terms of the impact on human and social aspects (LemańskaMajdzik, 2018). Much research indicates that small and medium enterprises (SMEs) are lagging behind the large ones in terms of pursuing sustainable development (SD) goals (Brammer et al., 2012; Cassells and Lewis, 2011). As SMEs have a major impact on employment, resource consumption and pollution, there arises the need to study the sustainability practices of SMEs around the globe (Yadav et al., 2018). SMEs are the economic core of most economies (Zorpas, 2010), which encourages the research into SD at the level of SMEs. Pioneering researchers have called for further consideration to be done to studies related to SMEs contribution to sustainability (Brammer et al., 2012). The significant impact of SMEs in terms of input and output requirements and the size of workforce they employ deserve special attention and engaging them in environmental improvement is regarded as a vital part of SD (Hillary, 2004).

The objective of the paper is to analyze the perception of sustainable performance of entrepreneurs being owners-managers of small businesses. The research tool was the questionnaire. The statistical analyses were conducted using the R Package.

\section{SUSTAINABLE DEVELOPMENT - THE CASE OF SMALL FIRMS}

As pointed out by Wiśniewska-Sałek (2018), in accordance with the Polish Environmental Protection Act, SD is understood as "[...] socio-economic development 
in which there takes place the process of integrating political, economic and social activities maintaining the natural balance and durability of basic natural processes in order to guarantee the possibility of satisfying basic needs of individual communities or citizens of both modern generation and future ones" (POS, 2001). The definition of SD is associated with the United Nations (UN) since the report of this organization recorded it for the first time in 1987 in Our Common Future as a result of the work of the World Commission on Environment and Development. Satisfying the needs of each of the key factors of sustainable development, being in the mutual correlation, is a very difficult process. Adamczyk and Nitkiewicz (2007) pay attention to the fact that the objectives of the enterprise are a set of interrelated pursuits, aspirations and intended effects. These objectives form a hierarchical system ensuring sustainable operation. Economic and environmental objectives are essentially linked by the harmony of objectives since the achievement of economic objectives often depends on the achievement of environmental objectives. Environmental protection can be the way to simultaneously improve economic performance, although, on the other hand, there may be the contradiction of objectives. Among social objectives, one may indicate guaranteeing the quality of life which, on the one hand, is determined by health, landscape, aesthetic conditions and, on the other, material conditions, such as labor market or infrastructure. The concept of corporate sustainability arises here. It is seen as a concept of SD at the corporate level with emphasis on performance in terms of the Triple Bottom Line. This approach advocates that the long-term success of an enterprise and its environment requires focus on all three dimensions of sustainability (economic, environmental, and social), rather than single, short term - only economic area of business (Lesníková and Schmidtová, 2019). This is also underlined by Ingaldi (2015), stating that the model of SD recognizes the importance of delivering sustainable economic value to shareholders by focusing on the bottom line profit that is generated. It also considers that if an enterprise is to be sustainable in the longer term, it needs to consider its performance in terms of the equivalent environmental and social "bottom lines".

Nowadays, organizations significantly contribute to SD of societies, which is also visible in ongoing activities of enterprises. Taking actions in line with the concept of sustainability requires an appropriate approach of the managerial staff and attitudes of employees as well as appropriate strategies for long-term action (Lemańska-Majdzik, 2018). SD, although it is conditioned macroeconomically, is created at the microeconomic level, and the role of the enterprise, as the smallest link responsible for its achievement, is crucial (Adamczyk, 2018). The human being is considered as an important entity of SD. The principles of enduring SD require that people, creating and sustaining the existence of the human world, include not only socio-economic factors in their operations but also environmental ones (Piątek, 2005). While paying attention to the role of the human being in the accomplishment of objectives of SD, it is worth referring to the idea of entrepreneurship which is immanently associated with the activities of people involved in business ventures.

The recognition of entrepreneurship as a solution to rather than a cause of environmental degradation and social inequality moved the field to identify a new type of entrepreneurial activity, namely sustainable entrepreneurship (Muñoz and Cohen, 2018). It can be interpreted as a spin-off concept from SD. Sustainable entrepreneurs are those that contribute to SD by doing business in a sustainable way (Crals and Vereeck, 2004). Sustainable entrepreneurs look for opportunities that offer the promise of both economic reward and environmental and social enhancement (Ploum et al., 
2018). Successful and sustainable entrepreneurship demands individuals with unique abilities and personality traits (Beattie, 2016). For SMEs, environmental leadership is becoming more essential given that the companies' size and limited resources often make it difficult to implement well-organized initiatives that effectively address sustainability issues (Revell et al., 2010). Environmental commitment of SMEs is often limited and cannot adequately develop without the support of top managers (Egri and Herman, 2000; Bansal 2003; Boiral et al., 2014). When analyzing the subordination of enterprises to SD or even partial application of the concept of SD in management, it should be noted that it is worth verifying the level of commitment of enterprises to SD both through generally accepted measures and the perception of people managing enterprises. In the case of small enterprises, it is about owners/managers who decide on the level of sustainability of enterprises they manage. The role of people managing enterprises is mentioned by Pabian (2019), paying attention to the role of sustainable managers. He claims that the negative influence of enterprises on the environment can be stopped by transforming them into sustainable enterprises. Sustainable managers possess knowledge and experience in both management as well as sustainability. Their features include social and ecological sensitivity, innovation and the ability to convince and motivate employees within the scope of sustainable development as well. Their objective is to create an organization whose mission, strategy and operational action programs include ecological and social initiatives.

The principles of sustainability help businesses to reduce risks, avoid waste generation, increase material and energy efficiency, innovate new, environmentally friendly products and services and obtain operating permits from local communities. Thus, by adopting sustainability principles, businesses can become more profitable and sustain their activities over the long term (Szekely and Knirsch, 2005). The application of solutions compliant with the concept of SD affects therefore the performance of the firm. Soto-Acosta et al. (2016) proved that sustainable entrepreneurship approaches towards people generate a significant positive influence on business performance. The entrepreneurs' openness and propensity towards yielding long-term benefits to the larger community and operating within business networks for achieving tenable benefits to the larger community and operating within business networks for achieving tenable economic goals have a significant positive influence on business performance.

\section{MATERIALS AND METHODS}

The research problem was formulated, which took the form of the following question: How do entrepreneurs perceive sustainable performance of their small firms? Having in mind the significance of management staff and an important role of the entrepreneur - owner/manager of the small business, the analysis of managerial perception of sustainable performance of the small firm was conducted, as an alternative way of determining the level of sustainability of the small company. For the purposes of the analysis, a part of the tool suggested for the analysis of the overall performance of small firms by Raymond et al. (2013) was used, which relates to the perception of the most important areas of performance of the small company by the owner/manager in the contemporary economic realities. In terms of the above, the performance of the small enterprise was operationalized through four dimensions, referring to separate aspects of the construct: enduring, sustainable, personal and economic performance.

Adequately to the research problem formulated in this paper, the dimension of "sustainable performance" was used for the research, indicating predispositions of 
people managing small enterprises to expand the group of stakeholders having impact on decisions translating into the performance of the company, including employers and fellow citizens; this dimension particularly applies to: sustaining employees, investing in the society, fulfilling customer expectations, providing a good quality of life to employees and achieving balance between the financial condition, social commitment and respect for the natural environment. The questions were oriented towards the determination and assessment of the current state of the enterprise by the entrepreneurs in the analyzed area. The respondents answered using the seven-point Likert scale, where 1 amounted to "definitely not" whereas 7 - "definitely yes". Individual questions addressed to the surveyed entrepreneurs were formulated in the following way: I think that, over the last three years, my company: Efficiently sustained employees (SUS_PERF1), Invested in the society (SUS_PERF2), Fulfilled customer expectations (SUS_PERF3), Provided a good quality of life for its employees (SUS_PERF4), Achieved balance between the financial condition, social commitment and respect for the natural environment (SUS_PERF5). The research, the results of which have been depicted in the present paper, was based on the method of conducting empirical studies by means of managerial perception (Miller and Friesen, 1978), in which data are obtained using the questionnaire. Performance measurement based on subjective measures is often used as a remedy for problems associated with the measurement based on objective measures (Sapienza et al., 1988).

The respondents of the research were the owners-managers of the analyzed enterprises. The research sample amounted to 129 small enterprises. The majority are the companies running their business activity in cities. These enterprises amount to $84.5 \%$, whereas the companies operating in the country constitute $15.5 \%$. The enterprise operating on the market for the shortest period of time is eight months old. The oldest one has been operating on the market for 26 years. The enterprises under consideration are both the companies characterized by self-employment, the ones not employing workers and the ones employing even 46 people. On average, the level of employment in the analyzed companies amounts to 4 employees (an entrepreneur +4 employees). For most of the surveyed companies, the basic activity is production $(30.2 \%)$. The activity associated with trade was identified as the domain of $33.3 \%$ of the surveyed companies. In the sector of services there operate $24 \%$ of the surveyed entities. The other $12.5 \%$ of the companies run their business activity in the field of the following sectors: construction, hotels and restaurants, transport, storage and communication, education and agriculture, hunting and forestry.

\section{RESULTS OF THE RESEARCH}

The perception of sustainable performance by the surveyed entrepreneurs, measured on the seven-point Likert scale, is presented in Table 1.

Table 1

The perception of sustainable performance by the surveyed entrepreneurs

\begin{tabular}{|l|l|l|l|l|l|}
\hline Variable & SUS_PERF1 & SUS_PERF2 & SUS_PERF3 & SUS_PERF4 & SUS_PERF5 \\
\hline Value & 4.31 & 3.21 & 5.51 & 4.35 & 4.37 \\
\hline
\end{tabular}

Source: own study

While assuming that, for the applied scale, the level 4 amounts to an average value (neutral), it can be concluded that the perception of the entrepreneurs fluctuates around 
average values except for the scale determining fulfillment of customer expectations and the scale relating to the sense of investing in the society. In the case of the perception of the efficient sustaining of employees the result exceeds the average value by $0.31 \mathrm{pt}$. The sense of fulfilment of expectations of customers, as company stakeholders, achieved the highest result (5.51), definitely exceeding the neutral level (by $1.51 \mathrm{pts}$ ). This area seems to be particularly important from the point of view of each entity conducting a business activity. Satisfying customer needs, generating value for customers are the areas which seem to be especially important. Achieving the level close to neutral could indicate even the dissatisfaction of the surveyed entrepreneurs with the conducted activity in terms of satisfying customer needs. This result, however, exceeds by far the neutral level. Nevertheless, it seems that it could achieve higher levels. On the other hand, the result of 5.51 may indicate the goals which are difficult to achieve, which entrepreneurs set to their companies and also that a certain level of satisfaction with meeting customer needs has been achieved, however, the state recognized at the time of the research is not adequate to the intentions yet.

Providing a good quality of life to employees and balance between the financial condition, social commitment and respect for the natural environment achieved the result close to the scale of SUS_PERF1 - respectively 4.35 and 4.37 . The obtained results indicate the awareness of the existing shortcomings in these areas. However, the indications at the level exceeding the neutral level seem to be important. It should be pinpointed that only in the case of one scale the obtained result did not achieve the value above the neutral level. This indicates a positive perception of the implementation of the assumptions of SD by the surveyed entrepreneurs. The individual components differ from each other, however, the entrepreneurs generally positively perceive the accomplishment of the assumptions/guidelines of SD. Perception of the level of investing in the society achieved the lowest level (3.21), which provokes some reflections. The obtained result is clearly the effect of little commitment to social problems of the surveyed entrepreneurs. This may be caused by a general low level of social capital in the case of the Polish society, which is also reflected in the actions and subsequently the feelings of the surveyed entrepreneurs. On the other hand, it is relevant that entrepreneurs are aware of their little commitment to "investing in the society". Obviously, the obtained result is not crushing, however, it indicates the poorest involvement in this area, which, in turn, the entrepreneurs themselves are aware of. Inviting entrepreneurs to take part in the research relating to the perception of the discussed areas can be regarded as the signal for the surveyed entrepreneurs emphasizing the significance of the discussed problems. Particularly the responses relating to fulfillment of customer needs, in spite of the satisfactory result, should initiate the process of the analysis and introduction of possible changes, aimed at improving the situation in this area so important from the business point of view.

The results of the analysis of the homogeneity of the scale applied to measure the performance of a sustainable small company are summarized in Table 2.

In the case of the scale concerning sustainable performance of the company, the Cronbach's Alpha achieves high values (0.847) and also none of the variables disrupts the scale. Descriptive statistics for the SUS_PERF variable, describing sustainable performance, is presented in Table 3.

On average, the level of sustainable performance amounted to 4.34 pts. This level deviates from the average value by $+/-1.51$ pt. At least $50 \%$ of the respondents found 
this level as not higher than 4.6 pts, at least $25 \%$ of the respondents - as not higher than 3.2 pts whereas at least $75 \%$ of the respondents - as not higher than 5.6 pts.

Table 2

Summary of SUS_PERF scale (5 items)

\begin{tabular}{|l|l|l|l|l|l|}
\hline & $\begin{array}{c}\text { Mean if item } \\
\text { deleted }\end{array}$ & $\begin{array}{c}\text { Variance if } \\
\text { item } \\
\text { deleted }\end{array}$ & $\begin{array}{c}\text { Standard } \\
\text { deviation } \\
\text { if item } \\
\text { deleted }\end{array}$ & $\begin{array}{c}\text { Correlation } \\
\text { between } \\
\text { the deleted } \\
\text { item and } \\
\text { sum of the } \\
\text { remaining }\end{array}$ & $\begin{array}{c}\text { Alpha if } \\
\text { item } \\
\text { deleted }\end{array}$ \\
\hline EF_2 SUS_PERF1 & 17.528 & 30.585 & 5.530 & 0.748 & 0.795 \\
\hline EF_3 SUS_PERF2 & 18.648 & 37.412 & 6.117 & 0.668 & 0.813 \\
\hline EF_4 SUS_PERF3 & 16.384 & 44.189 & 6.647 & 0.560 & 0.843 \\
\hline EF_6 SUS_PERF4 & 17.504 & 32.794 & 5.727 & 0.752 & 0.789 \\
\hline EF_12 SUS_PERF5 & 17.488 & 41.978 & 6.479 & 0.628 & 0.828 \\
\hline Mean=21.8880 Stand. deviation $=7.53189$ &
\end{tabular}

Source: own study

Table 3

Descriptive statistics for SUS_PERF variable

\begin{tabular}{|l|l|l|l|l|l|l|}
\hline Mean & $\begin{array}{c}\text { Standard } \\
\text { deviation }\end{array}$ & Median & Min. & Q25 & Q75 & Max. \\
\hline 4.34 & 1.51 & 4.60 & 0.60 & 3.20 & 5.60 & 7.00 \\
\hline
\end{tabular}

Source: own study

\section{CONCLUSIONS}

As pinpointed by Adamczyk (2018), sustainable development, initially as an idea, a new condition for enterprise management, over time, has become a standard for conducting a business activity. Acting in harmony with it strengthens the competitive position of the enterprise through an increase in economic and environmental efficiency and social acceptance. SD has changed the principles of the operation of enterprises and creates a new approach to management, aspiring to assume the role of a new paradigm.

The subject of the research has been selected small enterprises (including microenterprises) due to their share in a total number of enterprises in Poland (nearly 99\%) and also a steady increase in their number as well as an increase in the value of production, revenues, number of employees. In the years 2008-2016 it was the smallest enterprises that indicated the highest profitability against the background of the whole population of enterprises. As Moor and Manring (2009) point out, SMEs have a vital role to play in managing limited global environmental and social resources. A broad, multidimensional, multi-stakeholder perspective that is formed based on emerging ideas and trends should be the basis of a system approach towards an intentional, proactive situational analysis. A thoughtful, situational analysis, as the basis for developing the enterprise strategy, must incorporate new global stakeholders and should not be stagnant or reactionary.

Development prospects of the human world are open; however, it depends on human decisions whether this development will aim at enduring SD as well as on the manner in which people will organize themselves and act (Piątek, 2005). Therefore, taking note of this fact, an important entity of SD is the entrepreneur - the managing human being, 
the owner of the small enterprise who, while analyzing the environment, orients their company and thus shapes the mode of operation in the area of SD.

The obtained results clearly suggest the existence of certain deficiencies in the implementation of assumptions of SD in the surveyed small enterprises. Conducting the research on a representative sample of enterprises would enable the outline of the image which is the generalization relating to the Polish small firms. Such generalization could be the basis for creating a set of suggestions and recommendations for enterprises referring to the implementation of assumptions of SD at the level of the small enterprise. Conducting further research and supplementing it with more detailed information concerning the perception of the implementation of objectives of SD in SMEs can be particularly important in relation to the statement by Lemańska-Majdzik (2018) that enterprises recognize the contribution of their activities to SD, but small and medium-sized businesses are unable to do so or do not see the need to introduce this concept into strategic management or strategic goals of their organizations.

\section{REFERENCES}

Adamczyk, J., 2018. Zrównoważony rozwój jako paradygmat współczesnego zarządzania przedsiębiorstwem, Przegląd Organizacji, 12, 8-14.

Adamczyk, J., Nitkiewicz, T., 2007. Programowanie zrównoważonego rozwoju przedsiębiorstw, PWE, Warszawa.

Bansal, P., 2003. From issues to actions: The importance of individual concerns and organizational values in responding to natural environmental issues. Organization Science, 14(5), 510-527, https://doi.org/10.1287/orsc.14.5.510.16765.

Beattie, S., 2016. Which Entrepreneurial Traits are the Most Critical in Determining Success? Otago Manag. Grad. Rev.,14, 13-20.

Boiral, O., Baron, C., Gunnlaugson, O., 2014. Environmental leadership and consciousness development: A case study among Canadian SMEs. Journal of business ethics, 123(3), 363-383, http://dx.doi.org/10.1007/s10551-013-1845-5

Brammer, S., Hoejmose, S., Marchant, K., 2012. Environmental Management in SMEs in the UK: Practices, Pressures and Perceived Benefits. Business Strategy and the Environment, 21(7), 423-434. https://doi.org/10.1002/bse.717

Cassells, S., Lewis, K., 2011. SMEs and Environmental Responsibility: Do Actions Reflect Attitudes? Corporate Social Responsibility and Environmental Management, 199(3), 186-199. https://doi.org/10.1002/csr

Crals, E., Vereeck, L., 2004. Sustainable entrepreneurship in SMEs: theory and practice. 3rd Global Conference in Environmental Justice and Global Citizenship, Copenhagen, Denmark.

Egri, C.P., Herman, S., 2000. Leadership in the North American environmental sector: Values, leadership styles, and contexts of environmental leaders and their organizations. The Academy of Management Journal, 43(4), 571-604.

Hillary, R., 2004. Environmental management systems and the smaller enterprise. Journal of Cleaner Production, 12, 561-569

Ingaldi, M., 2015. Sustainability as an element of environmental management in companies, Production Engineering Archives, 7/2, 29-32, DOI: 10.30657/pea.2015.07.07

Lemańska-Majdzik, A., 2018. Flexible Activities of the Organization in Implementation of the Sustainable Development Principles in Selected Areas of the 
Organizations. European Journal of Sustainable Development, 7(4), 212-222, Doi: 10.14207/ejsd.2018.v7n4p212.

Lesníková, P., Schmidtová, J., 2019. Environmental Management in the Context of Corporate Sustainability Concept. System Safety: Human - Technical Facility Environment, 1(1), 352-362, doi:10.2478/czoto-2019-0045

Miller, D., Friesen, P.H., 1978. Archetypes of strategy formation. Management Science 24, 921-933.

Moore, S.B., Manring, S.L., 2009. Strategy development in small and medium sized enterprises for sustainability and increased value creation. Journal of cleaner production, 17(2), 276-282

Muñoz, P., Cohen, B., 2018. Sustainable entrepreneurship research: Taking stock and looking ahead. Business Strategy and the Environment, 27(3), 300-322, DOI: 10.1002/bse.2000.

Pabian, A., 2019. Sustainable Top Managers and their Activities in the Enterprise of the Future. System Safety: Human - Technical Facility - Environment, 1(1), 465-471, doi:10.2478/czoto-2019-0060

Piątek, Z., 2005. Człowiek jako podmiot zrównoważonego rozwoju: konsekwencje filozoficzno-społeczne, [in:] A. Papuziński (ed.), Zrównoważony rozwój. Od utopii do praw człowieka, Oficyna Wydawnicza Branta, Bydgoszcz, 14-29.

Ploum, L., Blok, V., Lans T., Omta O., 2018. Toward a validated competence framework for sustainable entrepreneurship. Organization\&Environment, 31(2), 113-132.

Prawo ochrony środowiska (POS) z dnia 27 kwietnia 2001 r., art.3, pkt.50.

Raymond, L., Marchand, M., St-Pierre, J., Cadieux,, L., Labelle, F., 2013. Dimensions of small business performance from the owner-manager's perspective: a reconceptualization and empirical validation, Entrepreneurship \& Regional Development, 25(5-6), 468-499.

Revell, A., Stokes, D., Chen, H., 2010. Small businesses and the environment: Turning over a new leaf? Business Strategy and the Environment, 19(5), 273-288

Sapienza, H.J., Smith, K.G., Gannon, M.J., 1988. Using Subjective Evaluations of Organizational Performance in Small Business Research, American Journal of Small Business, 12 (3), 45-53.

Soto-Acosta, P., Cismaru, D.M., Vătămănescu, E.M., Ciochină, R., 2016. Sustainable entrepreneurship in SMEs: A business performance perspective. Sustainability, 8(4), 342, 1-12.

Szekely F., Knirsch, M., 2005. Responsible Leadership and Corporate Social Responsibility: Metrics for Sustainable Performance, European Management Journal, 23, 6, 628-647, doi:10.1016/j.emj.2005.10.009

Wiśniewska-Sałek, A., 2018. Sustainable Development in Accordance with the Concept of Industry 4.0 on the Example of the Furniture Industry, $12^{\text {th }}$ International Conference Quality Production Improvement - QPI 2018, MATEC Web Conf. 183 04005, Vol. 183, DOI:10.1051/matecconf/201818304005

Yadav, N., Gupta, K., Rani, L., Rawat, D., 2018. Drivers of Sustainability Practices and SMEs: A Systematic Literature Review. European Journal of Sustainable Development, 7(4), 531-544, Doi: 10.14207/ejsd.2018.v7n4p531

Zorpas, A., 2010. Environmental management systems as sustainable tools in the way of life for the SMEs and VSMEs. Bioresource Technology, 101, 6, 1544-1557 doi: 10.1016/j.biortech.2009.10.022 